\title{
From Inside the DLP
}

\section{By Dr. Katharine M. Stokes}

College and University Library Specialist, Library Planning and Development Branch, Division of Library Programs, Bureau of Adult, Vocational, and Library Programs, U.S. Office of Education, Washington, D.C. 20202.

Nearly a year ago I talked with Joel Williams, Chief of the Library Surveys Branch of the National Center for Educational Statistics, about the prospects for publication, in time for ALA Midwinter, of Library Statistics of Colleges and Universities: Data for Individual Institutions, Fall 1968. In spite of his hopeful report at that time, the publication didn't appear until late this spring, though $\mathrm{Mr}$. Williams did make a copy of its preliminary computer-printout tables available for consultation at ALA headquarters during the January conference in Washington.

Dr. Bronson Price is working on the long promised Analytic Report, Fall 1968, which will probably appear early in 1970 . It is designed to enable any academic librarian to find, in the same position in every table, the data for his institution's particular peer group, e.g., public two-year community colleges having between 1,000 and 5,000 students, or private universities with over 10,000 students.

On September 22 notices were sent to the institutions reminding them of the October 1 due date for the Higher Education General Information Survey IV forms reporting fall 1969 library statistics. These statistics are coming in faster this year than last. On October 11, about 1,000 nonrespondents remained; on October 18, some 650 libraries were still to be heard from.

In eighteen states, the whole package of HEGIS forms is first sent to coordinators in State Boards of Higher Education for distribution to all or most of the campuses in their respective states. After these forms are completed by the schools they are again sent to the State Coordinators, who examine them and forward them to Washington in batches. This procedure is expected to lead to a reduced burden on respondents, to improve processing of data, and to acceleration of schedules. Until the procedure is fully developed, delays, over which individual librarians have no control, are being incurred.

Joel Williams is making no predictions about when the fall 1969 statistics will be published, but you can be sure that there is as much concern in the Library Surveys Branch of the NCES as in your own library that the Data for Individual Institutions be published early in 1970 ,
LATE NEws: If your Title II-A award for 1969 was $\$ 10,000$ or less, you should have received the total amount of the award this fall. If it was $\$ 10,001$ through $\$ 20,000$, you should have received one-half the amount. The other half will be scheduled for payment in March 1970 . Any amount over $\$ 20,000$ is payable in four equal installments. You should have received the first payment this fall; the other three will be paid in December 1969, March 1969, and June 1970.

LATE NEWS: A recent announcement by Commissioner Allen of reorganization plans for the Office of Education specifies a Deputy Commissioner for Instructional Resources (not yet appointed) who will administer two Bureaus, Education Personnel Development and Library Education Technology. The DLP will become part of the latter when the reorganization of the Office of Education is implemented.

\section{CALLING ALL CONSTRUCTION!}

Building? Remodeling? Expanding? We need your help. The Library Administration Division of ALA maintains a collection of building folders, slides and other information for people like you and we need your help to keep this collection current. These materials are used by people like you to plan for the future.

Interested? Write to:
Mrs. Virginia W. Baker
Professional Assistant
Library Administration Division
American Library Association
50 East Huron Street
Chicago, Illinois 60611

\section{LIBRARY BUILDINGS AWARD}

Entry slip forms for the 1970 Library Buildings Award Program are available from the Library Administration Division office at the American Library Association headquarters, 50 East Huron Street, Chicago, Illinois 60611. Entry slips must be completed by December 12, 1969. For details call Mrs. Ruth R. Frame, (312) 944-6790. 